\title{
Analisis Kesejahteraan Petani: Pola Penguasaan Lahan di Kabupaten Lamongan
}

\author{
Alfiana Ainurrahma ${ }^{1^{*}}$, Nunung Nuryartono ${ }^{2}$, Syamsul H. Pasaribu ${ }^{3}$ \\ Departemen Ilmu Ekonomi \\ Fakultas Ekonomi dan Manajemen, Institut Pertanian Bogor \\ *Korespondensi: alfiana.ainurrahma@gmail.com
}

[diterima: Juli 2018- revisi: September 2018-diterbitkan daring: Desember 2018]

\begin{abstract}
ABSTRAK
Pola penguasaan lahan mempengaruhi efektivitas sektor pertanian. Tujuan utama penelitian ini adalah menganalisis faktor-faktor yang mempengaruhi penguasaan lahan pertanian dan menghitung koefisien Gini penguasaan lahan pertanian di Kabupaten Lamongan. Data yang digunakan adalah data cross section rumah tangga usaha pertanian di Kabupaten Lamongan . Data diperoleh dari Sensus Pertanian 2013 dengan total observasi sebanyak 189343 rumah tangga pertanian. Penelitian ini menggunakan Analisis Regresi Berganda. Hasil penelitian menunjukkan bahwa usia kepala rumah tangga, jenis kelamin kepala rumah tangga, ukuran rumah tangga, dan jenis pendapatan utama secara signifikan mempengaruhi penguasaan lahan basah. Sedangkan faktor yang tidak signifikan mempengaruhi penguasaan lahan kering adalah jenis kelamin kepala rumah dan usia kepala rumah tangga. Terkait lahan basah sebagai sarana akumulasi aset bagi rumah tangga petani, hasil regresi menunjukkan bahwa petani mengalami penurunan dalam akumulasi marjinal lahan basah. Selain itu, koefisien Gini penguasaan lahan pertanian di Kabupaten Lamongan adalah 0.49 dan menunjukkan bahwa ketimpangan distribusi penguasaan lahan pertanian antar rumah tangga usaha pertanian di Kabupaten Lamongan cenderung moderat.
\end{abstract}

Kata kunci: Analisis Regresi Berganda, Akumulasi Aset, Koefisien Gini, Penguasaan Lahan

\begin{abstract}
Pattern of landholding affects effectiveness of the agricultural sector. This study aims to identify the determinants of landholding. The objectives are to identify the determinants of wet land and dry land held by farm household in Lamongan Regency and to calculate Gini coefficient of agricultural land in Lamongan Regency. Data was obtained from Agricultural Census 2013. Specifically, this study utilizes household cross sectional data with 189343 observations. This research utilizes multiple regression analysis. The results show that age, gender of head of household, household size, main source of income, and dummy for asset are significantly influencing wet landholding, while factors insignificantly affecting dry landholding is gender of head of household and age. Regarding wet land as asset accumulation for farm household, the results show that farmers experience a decreasing marginal accumulation on wet landholding. The Gini coefficient of agricultural land in Lamongan Regency is 0.49 and it shows that Lamongan Regency experiences moderate inequality in term of land holding.
\end{abstract}

Keywords: Asset Accumulation, Gini Coefficient of Land, Land holding, Multiple Regression Analysis JEL Classification: C31,Q13,Q15 


\section{PENDAHULUAN Latar Belakang}

Pertanian merupakan sektor yang penting bagi perekonomian Indonesia. Hal ini dikarenakan sektor pertanian memiliki banyak peran, antara lain dalam menyerap tenaga kerja, sumber bahan pangan, menyediakan input bagi industri, dan menunjang kehidupan bagi sebagian besar penduduk pedesaan. Ramadanti (2014) menyebutkan beberapa peranan strategis sektor pertanian antara lain pembentukan Produk Domestik Bruto (PDB) dan Produk Domestik Regional Bruto (PDRB), penyerapan tenaga kerja di level nasional dan regional, meningkatkan pendapatan masyarakat, dan menjaga nilai tukar. Oleh karena itu, Indonesia disebut sebagai negara agraris mengingat perekonomian Indonesia sangat tergantung pada sektor pertanian. Sektor pertanian berkembang secara konsisten meskipun kontribusi sektor pertanian dalam pembentukan PDB menurun dari tahun ke tahun. Penurunan kontribusi dalam pembentukan PDB disebabkan oleh meningkatnya peranan sektor sekunder dan sektor tersier, seperti pengolahan dan jasa (BPS, 2013).

Dalam penyerapan tenaga kerja, sektor pertanian menyerap 33.9 persen dari total tenaga kerja, atau sekitar 38973033 tenaga kerja pada bulan Agustus 2014. Angka tersebut mengalami penurunan dari periode sebelumnya, yakni berkisar pada angka 34.7 persen pada bulan Agustus 2013. Penurunan kontribusi sektor pertanian dalam penyerapan tenaga kerja disebabkan oleh menurunnya minat generasi muda dan tenaga kerja untuk menjadi petani (Supriyati, 2011). Kasryno (2000) juga menjelaskan bahwa masyarakat yang berpendidikan tinggi cenderung untuk bekerja pada sektor nonpertanian karena beberapa hal: (i) terbatasnya kesempatan untuk bekerja di sektor pertanian (ii) sektor pertanian relatif memberikan pendapatan yang berjangka panjang (iii) tingginya risiko ekonomi dalam sektor pertanian (iv) sektor pertanian memberikan pendapatan yang rendah (v) pertanian memberikan status sosial yang rendah.

Sebagai negara agraris, Indonesia menghasilkan berbagai komoditas pertanian.
Secara khusus, Pulau Jawa menjadi basis bagi produksi beras dan memiliki potensi yang tinggi dalam produksi tanaman pangan, hortikultura, peternakan, dan perikanan. Salah satu provinsi di Pulau Jawa, yakni Provinsi Jawa Timur, merupakan provinsi penghasil beras tertinggi secara nasional. Pada tahun 2013, total produksi beras Provinsi Jawa Timur sekitar 12398312 ton dari total produksi nasional 70831753 ton. Secara persentase, Provinsi Jawa Timur berkontribusi sekitar 17.5 persen dari total produksi beras nasional (Badan Pusat Statistik, 2013)

Bappenas dalam RPJMN 2015-2019 menyatakan bahwa ketahanan pangan menjadi salah satu prioritas utama yang hendak dicapai guna mewujudkan pembangunan yang berkelanjutan. Fakta bahwa Provinsi Jawa Timur merupakan provinsi dengan produksi beras tertinggi secara nasional, peran Provinsi Jawa Timur menjadi penting dalam rangka menyukseskan program-program ketahanan pangan yang sudah digagas. Hal ini tidak terlepas dari kondisi bahwa sampai saat ini, beras masih menjadi bahan pangan utama bagi sebagian besar penduduk Indonesia (Mubyarto, 1979).

Di satu sisi, Provinsi Jawa Timur cukup diandalkan dalam menunjang ketahanan pangan nasional. Namun ternyata, di sisi lain, Provinsi Jawa Timur masih mengalami tantangan yang bisa memengaruhi ketahanan pangan. Salah satu tantangan yang dihadapi adalah pertanian pada rumah tangga petani kaya.

Penguasaan lahan pertanian menjadi penting untuk dikaji berdasarkan fakta bahwa penguasaan lahan akan memengaruhi performa sektor pertanian. Tomich, Kilby, dan Johnston dalam Vollrath (2007) menyatakan bahwa konsentrasi penguasaan lahan yang tinggi menyebabkan keterbatasan pada sektor pertanian secara meluas. Vollrath (2007) menemukan bahwa kesenjangan penguasaan lahan mengurangi produksi pertanian secara signifikan. Chaudry et al. (1999) melakukan penelitian tentang korelasi antara penguasaan lahan dengan kemiskinan di Pakistan.

Hasil penelitian tersebut menunjukkan bahwa secara signifikan penguasaan lahan memiliki hubungan negatif terhadap tingkat kemiskinan. 
Ketika jumlah penguasaan lahan meningkat, tingkat kemiskinan akan menurun. Darwis (2008) melakukan penelitian terhadap rumah tangga usaha pertanian di Provinsi Jawa Barat dan Provinsi Sulawesi Selatan. Hasil penelitian tersebut menunjukkan bahwa pendapatan petani di Indonesia sangat tergantung pada luasan lahan pertanian yang dimiliki. Booth (2002) berargumentasi bahwa dari hasil Sensus Penduduk Antar Sensus (SUPAS) tahun 1995, terindikasi bahwa 46 persen rumah tangga di area pedesaan menjadikan pertanian sebagai sumber utama pendapatan rumah tangga mereka. Pada tahun 1993.83 persen petani pemilik lahan juga sangat tergantung pada pertanian. Berdasarkan studi Yunilisiah (1996), jumlah lahan yang dikuasai rumah tangga usaha pertanian menjadi faktor utama yang menentukan besarnya total pendapatan rumah tangga usaha pertanian. Ketika lahan yang dikuasai oleh rumah tangga luas, maka total pendapatan rumah tangga akan meningkat.

Di Indonesia, permasalahan lahan menjadi tantangan tersendiri. Badan Ketahanan Pangan (2014) secara jelas menyatakan bahwa permasalahan lahan menjadi salah satu kunci utama dalam sistem ketahanan pangan nasional. Hal ini didukung oleh penelitian Beyene dan Muche (2010) serta Muche dan Tagebe (2015) di Ethiopia dan menunjukkan bahwa ketahanan pangan turut dipengaruhi oleh penguasaan lahan. Penelitian dengan hasil yang sama juga ditemukan oleh Joshi dan Maharjan (2007) di Nepal. Perubahan struktur penguasaan lahan yang menyebabkan ketimpangan menjadi salah satu tantangan yang harus diselesaikan karena dapat menimbulkan permasalahan lain, antara lain memengaruhi ketahanan pangan.

Data Sensus Pertanian 2013 menunjukkan bahwa telah terjadi perubahan struktur penguasaan lahan dan membuat sebagian kecil penduduk menguasai lahan yang sangat luas. Di tahun 2003, rumah tangga usaha tani di Indonesia dengan luas lahan kurang dari $1000 \mathrm{~m}^{2}$ sejumlah 9380000 rumah tangga. Di tahun 2013, jumlah tersebut menjadi hanya 4338849 rumah tangga. Di sisi lain, jumlah rumah tangga usaha pertanian dengan luas lahan lebih dari $30000 \mathrm{~m}^{2}$ jumlahnya meningkat dari 1309896 rumah tangga di tahun 2003 menjadi 1608728 rumah tangga di tahun
2013. Di Provinsi Jawa Timur juga telah terjadi perubahan dalam struktur penguasaan lahan. Tren yang terjadi adalah sama. Jumlah rumah tangga yang menguasai lahan kurang dari $1000 \mathrm{~m}^{2}$ jumlahnya menurun seiring dengan peningkatan jumah rumah tangga dengan penguasaan lahan lebih dari $30000 \mathrm{~m}^{2}$.

Tren penurunan jumlah rumah tangga usaha pertanian kecil yang diiringi oleh peningkatan jumlah rumah tangga usaha pertanian besar kemungkinan terjadi akibat beberapa faktor. Faktor tersebut antara lain: (i) peningkatan jumlah petani dengan lahan lebih dari 1 hektar (ii) pergeseran struktur aktivitas ekonomi ke sektor non-pertanian dan (iii) petani kecil menjadi buruh (BPS, 2013).

Secara spesifik, studi ini mengambil Kabupaten Lamongan sebagai studi kasus. Kabupaten Lamongan merupakan salah satu kabupaten di Provinsi Jawa Timur dengan total produksi beras tertinggi. Total produksi beras Kabupaten Lamongan pada tahun 2013 adalah sebanyak 846275 ton yang terdiri dari 797596 ton padi sawah dan 48679 ton padi ladang. Dalam persentase, Kabupaten Lamongan berkontribusi sebanyak 7.2 persen terhadap total produksi beras di Provinsi Jawa Timur (BPS, 2013). Total produksi padi Kabupaten Lamongan yang cukup tinggi sejalan dengan ukuran luas panen padi Kabupaten Lamongan yang juga tinggi. Kabupaten Lamongan menjadi salah satu kabupaten di Provinsi Jawa Timur dengan panen padi terluas, yakni 144910 hektar pada tahun 2013 yang terdiri dari 135925 hektar padi sawah dan 8985 hektar padi ladang. Kabupaten Lamongan juga merupakan salah satu kabupaten di Provinsi Jawa Timur dengan jumlah rumah tangga usaha tani padi tertinggi. Kabupaten Lamongan memiliki 160306 rumah tangga usaha tani padi pada tahun 2013. Jumlah ini sekitar 92 persen dari total rumah tangga usaha tani tanaman pangan di Kabupaten Lamongan dan 5.5 persen dari total rumah tangga usaha tani padi di Provinsi Jawa Timur (BPS, 2013).

Penelitian ini memfokuskan objek penelitian pada faktor-faktor yang memengaruhi penguasaan lahan sawah di Kabupaten Lamongan. Spesifikasi penelitian untuk menganalisis faktor-faktor yang memengaruhi penguasaan lahan sawah diadaptasi dari 
penelitian Pomp (1995). Penelitian tersebut memisahkan antara lahan sawah dan lahan bukan sawah (lahan kering) karena lahan sawah memiliki nilai yang lebih tinggi dibandingkan lahan bukan sawah. Selain itu, berdasarkan Minardi (1979), lahan sawah memiliki peran yang lebih besar dalam produksi tanaman pangan. Hal tersebut didukung oleh kondisi riil di Indonesia bahwa lahan sawah memiliki luas lahan garapan yang lebih besar dibandingkan luas lahan garapan bukan sawah (BPS, 2013). Jumlah rumah tangga usaha pertanian yang terlibat dalam usaha pertanian sawah (padi sawah) jumlahnya jauh lebih besar dibandingkan jumlah rumah tangga usaha pertanian yang terlibat di usaha pertanian bukan sawah (padi ladang dan palawija). Selain itu, fakta dari Panel Petani Nasional (Patanas) tahun 2007 menunjukkan bahwa segmen tertinggi penguasaan lahan oleh petani-petani di Pulau Jawa adalah lahan sawah, yakni 86 persen dari total lahan yang dikuasai. Hal tersebut juga terjadi di luar Pulau Jawa, dengan segmen penguasaan lahan sawah mencapai 64 persen.

Selain menganalisis faktor-faktor yang memengaruhi penguasaan lahan pertanian, penelitian ini juga bertujuan untuk melihat besarnya ketimpangan penguasaan lahan pertanian di Kabupaten Lamongan. Hal tersebut didasari oleh data bahwa telah terjadi perubahan dalam struktur penguasaan lahan dan jumlah petani besar meningkat seiring dengan menurunnya jumlah petani kecil pada selang waktu tahun 2003 dan tahun 2013. Ketimpangan tersebut cukup penting untuk diketahui karena berdasarkan Bachriadi dan Winardi (2011), dua kondisi utama yang berkontribusi terhadap tingginya tingkat kemiskinan salah satunya adalah meningkatnya jumlah buruh tani. Nuryartono (2005) juga menjelaskan bahwa menganalisis distribusi penguasaan lahan penting untuk mengetahui seberapa besar ketimpangan penguasaan antar rumah tangga. Ketimpangan tersebut, jika tinggi rawan menyebabkan konflik.

Berdasarkan berbagai uraian di atas, pertanyaan utama penelitian ini adalah: (1) apa saja faktor-faktor yang memengaruhi penguasaan lahan pertanian di Kabupaten Lamongan? (2) bagaimana koefisien Gini penguasaan lahan pertanian di Kabupaten Lamongan?

\section{TINJAUAN PUSTAKA Konsep Penguasaan Lahan}

Badan Pusat Statistik (2013) mendefinisikan lahan yang dikuasai adalah lahan milik sendiri, ditambah lahan yang berasal dari pihak lain, dan dikurangi oleh lahan yang berada di pihak lain. Lahan tersebut bisa berupa lahan sawah dan atau lahan bukan sawah (lahan kering).

Deininger et al. (2003) mendefinisikan penguasaan lahan sebagai hak atas lahan dan menentukan akses terhadap lahan serta manfaat yang dihasilkan dari lahan tersebut. Pemerintah Amerika Serikat seperti dijelaskan dalam Agricultural Resources and Environmental Indicators mendefinisikan penguasaan lahan secara luas. Penguasaan lahan mencakup kepemilikan sederhana seperti sewa hingga hak untuk menjadikan lahan sebagai sarana peringanan dan jaminan oleh pemerintah atau swasta. FAO mendefinisikan penguasaan lahan sebagai hubungan secara legal antar masyarakat baik perorangan maupun kelompok dalam kaitannya terhadap lahan. Dalam konteks yang lebih sederhana, penguasaan lahan menentukan siapa yang berhak menggunakan sumber daya dari suatu lahan dan berapa lama dia serta kondisi apa saja yang membuat dia berhak menggunakan sumber daya tersebut. The Environmental and Natural Resources Policy and Training Project (EPAT), sebuah riset yang didanai oleh USAID pada tahun 1995, mendefiniskan penguasaan lahan sebagai akses petani terhadap sumber daya, seara spesifik merujuk pada kondisi bagaimana petani-petani tersebut membuat keputusan terkait pemanfaatan lahan dan investasi lahan tersebut.

Pomp (1995) menjelaskan mengenai hal-hal yang memengaruhi perbedaan akses terhadap penguasaan lahan, antara lain: (i) perbedaan pada jumlah lahan yang diinginkan terkait dengan perbedaan ketersediaan tenaga kerja dan kemampuan tenaga kerja (ii) perbedaan akses terhadap lahan yang disebabkan oleh lamanya waktu tinggal di suatu wilayah (iii) perbedaan pada kemampuan dalam membiayai akuisisi lahan.

Deininger et al. (2003) juga menjelaskan mengapa penguasaan lahan penting. Penguasaan lahan mengambil peranan penting dalam keamanan pangan dan mengurangi kemiskinan. Keamanan pangan bisa terpengaruh karena 
perseorangan dan keluarga bisa dikatakan amanpangan tergantung dari besarnya kesempatan yang dimiliki untuk menguasai aset seperti lahan, sama pentingnya seperti kesempatan dalam mengakses pasar dan peluang ekonomis lainnya. Keluarga dan perseorangan yang memiliki lahan cenderung lebih baik dibandingkan mereka yang tidak memiliki lahan. Penguasaan lahan juga penting dalam kaitannya dengan pembangunan pedesaan. Hak atas lahan adalah sarana yang efektif membangun aset bagi masyarakat sehingga mereka bisa memperoleh kehidupan yang berkelanjutan. Hak atas lahan juga sumber daya yang ampuh bagi masyarakat untuk meningkatkan dan memperluas aset selain lahan, seperti aset dalam sumber daya alam, sosial, keuangan dan aset fisik lainnya.

Rahman dan Manprasert (2006) menghubungkan landless sebagai manifestasi dari kemiskinan, kerawanan, buruknya akses kredit, dan lemahnya rumah tangga pedesaan. Hidalgo et al. (2008) berargumen bahwa tingginya kesenjangan pada penguasaan lahan diasosiasikan dengan tingginya persentase masyarakat miskin dan membuat perekonomian menjadi sensitif terhadap guncangan. Myrdal dalam Asian Drama seperti dikutip dari Todaro dan Smith (2006) mengindentifikasi tiga elemen yang membentuk pola penguasaan lahan di Asia: kolonialisme oleh Eropa, tingginya monetisasi, dan tingginya pertumbuhan pendudukan. Maxwell dan Wiebe (1998) menjelaskan bahwa penguasaan lahan juga diperoleh dari pernikahan, kekuasaan, dan warisan.

Berdasarkan Undang-Undang Nomor 5 Tahun 1960 tentang Peraturan Dasar Pokok-Pokok Agraria, hak akan lahan meliputi hak milik, hak guna-usaha, hak guna bangunan, hak pakai, hak sewa, hak membuka tanah, hak memungut hasil hutan, dan hak-hak lainnya. Berdasarkan Susilawati et al. (2010), penguasaan lahan di Indonesia terbagi ke dalam dua kelompok besar yakni (i) milik sendiri (ii) bukan milik, yang terdiri dari sewa, bagi hasil, gadai, dan lainnya. Susilowati et al. (2010) juga menjelaskan bahwa di awal 1980, dua kelompok peneliti memiliki kesimpulan yang berbeda mengenai pola penguasaan lahan di Indonesia. Kelompok pertama terdiri dari Geertz, Hayami, dan Kikuchi yang menyatakan bahwa masyarakat pedesaan di
Pulau Jawa tidak terpolarisasi menjadi tuan tanah dan buruh tani, melainkan mereka berada pada pola yang terstratifikasi. Kelompok lain terdiri dari Sayogyo, Collier, Lyon, dan Kano yang menyatakan bahwa polarisasi penguasaan lahan di pedesaan benar-benar terjadi dan hal tersebut dibuktikan oleh Sensus Pertanian Tahun 19831993.

\section{Konsep Koefisien Gini Penguasaan Lahan}

Konsep koefisien Gini menurut Todaro dan Smith (2012) adalah ukuran numerik yang secara agregat mengukur ketimpangan dan memiliki nilai antara 0 (pemerataan sempurna) hingga 1 (ketimpangan sempurna). Koefisien Gini bisa diukur secara grafis dengan membagi area antara garis pemerataan sempurna 45 derajat dan kurva Lorenz dengan total area di atas garis pemerataan sempurna di kurva Lorenz. Semakin tinggi nilai koefisien Gini, semakin besar ketimpangan dan berlaku pula sebaliknya.

Zheng et al. (2013) menjelaskan bahwa pada awalnya koefisien Gini digunakan untuk mengitung ketimpangan distribusi pendapatan, namun saat ini koefisien Gini juga bisa digunakan untuk menganalisis struktur ketimpangan dalam penguasaan lahan. Todaro dan Smith (2012) mengatakan bahwa nilai koefisien Gini bervariasi dari 0 (pemerataan sempurna) hingga 1 (ketimpangan sempurna). Pengukuran ketimpangan menggunakan koefisien Gini memberikan konsekuensi bahwa beberapa prinsip yang membangun penghitungan tersebut sudah terpenuhi, yaitu:

(i) the anonymity, bahwa pengukuran ketimpangan menggunakan koefisien Gini tidak memedulikan siapa yang menjadi subjek dari pengukuran. Artinya, koefisien Gini tidak memerhitungkan apakah yang menguasai lahan luas adalah orang baik atau orang jahat

(ii) the scale independence, bahwa pengukuran ketimpangan menggunakan koefisien Gini tidak memedulikan satuan pengukuranapakah dalam hektar, meter, rupiah, atau dolar-karena pengukuran menggunakan koefisien Gini hanya fokus pada ketimpangan bukan pada ukuran ketimpangan tersebut 
(iii) the population independence, bahwa pengukuran menggunakan koefisien Gini tidak berdasar pada jumlah penerima lahan. Jika dilakukan transfer lahan dari petani kaya ke petani miskin, distribusi lahan yang baru akan lebih merata.

Selain menggunakan kurva Lorenz, menghitung koefisien Gini bisa dilakukan melalui beberapa cara yang lain. Khattak dan Hussain (2008) menderivasi persamaan di bawah ini untuk menghitung koefisien Gini penguasaan lahan.

$\mathrm{G}=1+\frac{1}{n}+\frac{2}{n^{2}}+\overline{\mathrm{A}}\left[A_{1}+2 \mathrm{~A}_{2}+3 \mathrm{~A}_{3}+\ldots+\mathrm{nA}_{\mathrm{n}}\right]$

Notasi $G$ adalah koefisien Gini penguasaan lahan dan $\bar{A}$ adalah rata-rata luas lahan yang dikuasai. Jamal dan Khan (2005) juga mengenalkan metode penghitungan koefisien Gini dalam tipe data kategori. Persamaan di bawah menjelaskan mengenai penghitungan koefisien Gini dalam tipe data kategori.

$$
\text { Gini }=\left|1-\sum_{i=1}^{N}\left(\sigma Y_{i-1}+\sigma Y_{i}\right)\left(\sigma X_{i-1}-\sigma X_{i}\right)\right|
$$

Notasi $\mathrm{N}$ adalah jumlah kategori, $\sigma$ adalah nilai distribusi kumulatif, dan $\mathrm{Y}, \mathrm{X}$ adalah proporsi rumah tangga usaha pertanian dan luas lahan yang dikuasai. Vollrath (2006) juga memberikan cara untuk menghitung koefisien Gini penguasaan lahan dalam data yang bersifat kategorik. Cara tersebut mengadopsi cara yang digunakan oleh Deininger dan Squire (1996). Persamaan yang digunakan adalah sebagai berikut:

$$
G=1-\sum_{i=1}^{i=n}\left(F_{i+1}-F_{i}\right)\left(\left(A_{i+1}+A_{i}\right)\right.
$$

Notasi $f_{i}$ adalah share dari semua rumah tangga usaha pertanian yang berada di kategori $i$ terhadap total rumah tangga keseluruhan sehingga $\sum_{s=1}^{i} f s$ sedangkan $\alpha_{\mathrm{i}}$ adalah share semua lahan yang berada dalam kategori $i$ terhadap total luas lahan keseluruhan sehingga $\sum_{S=1}^{i} \alpha s$.

Jenkins dalam Nuryartono mendeskripsikan cara lain untuk menghitung koefisien Gini. Cara tersebut dijelaskan oleh persamaan berikut:

$$
G=1+\frac{1}{N}-\left(\frac{2}{m \cdot N^{2}}\right) \cdot \sum_{i=1}^{N}(N-i-1) \cdot Y i
$$

Notasi $\mathrm{N}$ adalah total populasi, $\mathrm{m}$ adalah rataan total luasan lahan, dan $\mathrm{Yi}$ adalah luas lahan yang dimiliki rumah tangga ke-i.

\section{METODE Jenis dan Sumber Data}

Data yang digunakan diperoleh dari Sensus Pertanian 2013 yang dikeluarkan oleh Badan Pusat Statistik. Secara spesifik, studi ini menggunakan data cross-section rumah tangga pertanian Kabupaten Lamongan. Untuk analisis data, digunakan software STATA dan Microsoft Excel 2013

\section{Metode Analisis dan Pengolahan Data}

Metode analisis yang digunakan dalam penelitian ini disesuaikan dengan tujuan penelitian, yaitu metode analisis regresi linier berganda dan analisis penghitungan Koefisien Gini

1. Model Analisis Faktor yang Memengaruhi Penguasaan Lahan

Analisis Regresi Linier Berganda digunakan untuk menganalisis faktor-faktor yang memengaruhi penguasaan lahan di Kabupaten Lamongan. Variabel penjelas yang digunakan antara lain: (i) usia kepala rumah tangga (Age) (ii) jenis kelamin kepala rumah tangga (GendHoH) (iii) jenis pendapatan utama rumah tangga (SourcInc), dan (iv) ukuran rumah tangga (HHSize). Jenis kelamin kepala rumah tangga $(\mathrm{GendHoH})$ adalah variabel dummy yang akan bernilai 1 jika kepala rumah tangga adalah perempuan. Jenis sumber pendapatan utama rumah tangga juga merupakan variabel dummy dan bernilai 1 jika sumber pendapatan rumah tangga utama adalah sektor pertanian. Variabel dummy DumWL, DumDL, dan DumDLWL menunjukkan kepemilikan lahan sawah dan lahan bukan sawah oleh rumah tangga dan menentukan kemampuan rumah tangga dalam menguasai lahan. DumWL dan DumDL bernilai 1 jika kepemilikan masing-masing 
jenis lahan di atas rata-rata. DumDLWL bernilai 2 jika rumah tangga memiliki lahan sawah sekaligus lahan bukan sawah di atas rata-rata. Satu kategori kepemilikan lain adalah kepemilikan lahan sawah sekaligus lahan bukan sawah di bawah rata-rata. Kategori tersebut memiliki dummy bernilai 0 sehingga tidak perlu dimasukkan ke dalam model. Variabel dependen yang terlibat dalam model $(\mathrm{Y})$ adalah luas lahan sawah $\left(\mathrm{m}^{2}\right)$ dan luas lahan bukan sawah $\left(\mathrm{m}^{2}\right)$.

Persamaan berikut ini digunakan untuk mengestimasi faktor-faktor yang memengaruhi penguasaan lahan di Kabupaten Lamongan yang diadaptasi dari Pomp (1995).

$$
\begin{array}{r}
Y=f(\text { Age }, \text { AgeSq, SourcInc, HHSize, } \\
\text { DumWL,DumDL DumDLWL,e })
\end{array}
$$

di mana:

$\begin{aligned} \text { Age, AgeSq }= & \text { usia kepala rumah tangga } \\ & \text { (tahun) dan usia kepala } \\ & \text { eumah tangga kuadrat } \\ = & \text { jenis kelamin kepala } \\ & \text { rumah tangga } \\ = & \text { jenis sumber pendapatan } \\ & \text { utama rumah tangga } \\ \text { SourcInc } & \text { ukuran rumah tangga } \\ & \text { (orang) } \\ \text { HHSize } & \text { dummy kepemilikan lahan } \\ & \text { sawah di atas rata-rata } \\ \text { DumWL } & \text { dummy kepemilikan lahan } \\ & \text { bukan sawah di atas rata- } \\ \text { DumDL } & \text { rata } \\ = & \text { dummy kepemilikan lahan } \\ & \text { sawah dan lahan bukan } \\ & \text { sawah di atas rata-rata } \\ = & \text { penguasaan lahan sawah } \\ \text { DumDLWL } & \text { atau lahan bukan sawah } \\ = & \text { galat }\end{aligned}$

2. Koefisien Gini Penguasaan Lahan

Untuk menghitung koefisien Gini penguasaan lahan, riset ini mengadaptasi cara yang dilakukan Jenkins dalam Nuryartono (2005). Persamaan penghitungan koefisien Gini sama dengan persamaan (4) dan ditulis ulang sebagai berikut:

$$
G=1+\frac{1}{N}-\left(\frac{2}{m \cdot N^{2}}\right) \cdot \sum_{i=1}^{N}(N-i-1) \cdot Y i
$$

Notasi $\mathrm{N}$ adalah total populasi, $\mathrm{m}$ adalah rataan total luasan lahan, dan Yi adalah luas lahan yang dimiliki rumah tangga ke-i.

Di samping menghitung koefisien Gini, kurva Lorenz juga penting untuk melihat sejauh mana pemerataan distribusi lahan dan seberapa besar ketimpangan distribusi dari pemerataan sempurna. Tahapan-tahapan untuk membuat kurva Lorenz adalah sebagai berikut.

1. Menghitung nilai dari 20 persen, 40 persen, 60 persen, dan 80 persen dari jumlah rumah tangga

2. Melakukan penghitungan jumlah lahan yang dikuasai oleh 20 persen, 40 persen, 60 persen, dan 80 persen rumah tangga tersebut. Jumlah lahan yang dimiliki oleh masing-masing kelompok rumah tangga kemudian dibuat persentase terhadap luas lahan total

3. Melakukan plotting secara kumulatif. Persentase penduduk di-plot secara kumulatif ke sumbu $X$ dan persentase luas lahan yang dikuasai per kelompok penduduk di-plot ke sumbu Y.

4. Menghubungkan setiap titik pertemuan nilai kumulatif $\mathrm{X}$ dan $\mathrm{Y}$ untuk melihat besarnya ketimpangan dari garis pemerataan sempurna.

\section{HASIL DAN PEMBAHASAN \\ Gambaran Umum}

Berdasarkan data yang telah diperoleh, populasi rumah tangga usaha pertanian di Kabupaten Lamongan secara dominan dikepalai oleh laki-laki. Jumlah rumah tangga dengan kepala rumah tangga laki-laki sekitar 168009 rumah tangga dari total keseluruhan rumah tangga 189343 rumah tangga. Dalam persentase, jumlah rumah tangga yang dikepalai laki-laki mencapai 88.78 persen. Berdasarkan Chendo et al. (2014), jenis pekerjaan di sektor pertanian yang membutuhkan tenaga besar membuat lakilaki lebih banyak terlibat dan lebih produktif dibandingkan laki-laki.

Untuk karakteristik sumber utama pendapatan rumah tangga usaha pertanian, diketahui bahwa mayoritas rumah tangga mengandalkan sektor pertanian sebagai sumber pemasukan utama. Jumlah tersebut mencapai 87.62 persen atau 
sekitar 165895 rumah tangga dari total 189343 rumah tangga yang ada.

Karakteristik usia kepala rumah tangga usaha pertanian di Kabupaten Lamongan didominasi oleh usia 50 tahun. Jumlah rumah tangga usaha pertanian yang dikepalai petani berusia 50 tahun sekitar 11343 rumah tangga dari total 189343 rumah tangga. Kepala rumah tangga termuda berusia 10 tahun sebanyak 10 rumah tangga dan kepala rumah tangga tertua berusia 99 tahun yakni sebanyak 270 rumah tangga. Karakteristik rumah tangga usaha pertanian Kabupaten Lamongan memiliki ukuran rumah tangga ratarata 4 orang per rumah tangga. Nilai rata-rata ukuran rumah tangga tersebut sama dengan nilai mayoritas ukuran rumah tangga sebanyak 4 orang per rumah tangga, yakni 26.69 persen. Struktur lahan pertanian di Kabupaten Lamongan didominasi oleh lahan sawah seluas kurang lebih 71995.7 hektar dan pertanian lahan kering atau lahan bukan sawah seluas 23342.25 hektar. Dari jumlah lahan sawah tersebut, sejumlah 1256.7 hektar merupakan sawah rawa lebak, 475.58 adalah sawah pasang surut, 34087.5 hektar sawah tadah hujan, 26263.46 hektar sawah dari irigasi lain, dan 9912.38 hektar merupakan sawah irigasi teknis.

Luasnya lahan sawah dan lahan bukan sawah di Kabupaten Lamongan membuat potensi pertanian di Kabupaten Lamongan cukup besar. Kabupaten Lamongan berpotensi untuk menciptakan swasembada pangan terutama melalui program-program yang sudah dicanangkan pemerintah yakni ekstensifikasi, intensifikasi, diversifikasi, serta rehabilitasi. Selain itu, tidak menutup kemungkinan adanya pembukaan lahan-lahan baru yang diperuntukkan bagi pertanian daerah. Tingginya potensi pertanian Kabupaten Lamongan terlihat dari jumlah total produksi padi pada tahun 2013 dan membuat Kabupaten Lamongan menjadi salah satu kabupaten di Provinsi Jawa Timur dengan produksi padi tertinggi. Selain itu, mengingat besarnya luas lahan sawah, padi masih menjadi komoditas pangan utama yang diproduksi oleh Kabupaten Lamongan dan masih mejadi prioritas tanaman pangan yang diusahakan petani karena luas panen padi adalah yang paling tinggi jika dibandingkan luas panen komoditas pangan yang lain.

\section{Faktor-faktor yang Mempengaruhi Penguasaan Lahan di Kabupaten Lamongan}

Analisis regresi linier berganda digunakan sebagai metode ekonometrika untuk menganalisis faktor-faktor yang memengaruhi penguasaan lahan di Kabupaten Lamongan. Data yang digunakan dalam analisis adalah data Sensus Pertanian Kabupaten Lamongan tahun 2013. Observasi berada pada level rumah tangga dan terdiri dari 189343 rumah tangga.

Tabel 1 dibawah ini merangkum hasil analisis regresi linier berganda dan memberikan penjelasan mengenai faktor-faktor yang memengaruhi penguasaan lahan sawah. Model tersebut signifikan secara statistik dengan nilai Pvalue adalah 0.000 pada taraf nyata 1 persen.

Semua variabel yang terlibat dalam model signifikan pada taraf nyata 1 persen. Usia kepala rumah tangga (Age), jenis pendapatan utama rumah tangga (SourcInc), dan ukuran rumah tangga (HHSize) secara positif memengaruhi penguasaan lahan. Artinya, seiring dengan bertambahnya usia kepala rumah tangga dan ukuran rumah tangga, maka penguasaan lahan sawah per rumah tangga usaha pertanian juga akan naik. Jika sumber pendapatan rumah tangga bersumber dari pertanian, rata-rata luas lahan sawah yang dikuasai rumah tangga juga akan lebih tinggi dibandingkan rata-rata luas lahan sawah yang dimiliki rumah tangga dengan sumber pendapatan utama bukan dari pertanian. Untuk jenis kelamin kepala rumah tangga, ratarata luas lahan sawah yang dimiliki rumah tangga dengan kepala rumah tangga perempuan lebih sedikit jika dibandingkan rata-rata luas lahan sawah yang dimiliki rumah tangga dengan kepala rumah tangga laki-laki. 
Tabel 1. Hasil Estimasi Faktor yang Memengaruhi Penguasan Lahan di Kab. Lamongan

\begin{tabular}{ccc}
\hline Variabel & Koefisien & P-value \\
\hline Age* & .014659 & 0.000 \\
AgeSq* & -.0001186 & 0.000 \\
HHSize* & .1568562 & 0.000 \\
SourcInc* & .1284221 & 0.000 \\
GendHoH* & -.0922142 & 0.000 \\
DumDL* & .0162874 & 0.000 \\
DumWL* & 1.322103 & 0.000 \\
DumDLWL* & .06260142 & 0.000 \\
const* & 6.882009 & 0.000 \\
\hline
\end{tabular}

Keterangan : *) Signifikan pada taraf nyata 1 persen

Hasil analisis di atas sama halnya dengan hasil riset yang dilakukan oleh Pomp (1995). Pomp menemukan bahwa usia kepala rumah tangga, jenis pendapatan utama, jenis kelamin kepala rumah tangga, dan ukuran rumah tangga secara signifikan memengaruhi kepemilikan lahan di Sulawesi Selatan. Ukoha et al. (2012) juga menemukan bahwa usia kepala rumah tangga dan jenis penerimaan utama memengaruhi penguasaan lahan secara signifikan. Demikian halnya dengan Chendo et al. (2014) yang juga membuktikan bahwa jenis kelamin kepala rumah tangga secara signifikan memengaruhi penguasaan lahan.

Usia kepala rumah tangga cenderung memiliki pengaruh positif terhadap penguasaan lahan sawah per rumah tangga usaha pertanian karena telah menjadi budaya bagi masyarakat Suku Jawa dan rumah tangga petani untuk mengakumulasi lahan sawah sebagai aset utama rumah tangga. Pengaruh usia terhadap peningkatan jumlah lahan sawah sebagai aset bisa dijelaskan melalui Teori Siklus Kehidupan dan Akumulasi Aset yang dicetuskan oleh Modigliani.

Aset berupa lahan sawah diakumulasi oleh petani selama masa produktif mereka yang berkisar 50 tahun. Aset lahan sawah akan didisakumulasi ketika petani memasuki usia tua dan sudah tidak produktif lagi dan pada kasus rumah tangga petani di Kabupaten Lamongan, puncak usia produktif adalah 50 tahun. Artinya setelah usia 50 tahun, petani cenderung melakukan diakumulasi aset. Bentuk disakumulasi aset lahan sawah adalah melalui turn-over lahan. Penyebab terjadinya turn-over lahan dijelaskan oleh Anggraeni (2009), antara lain: tingginya biaya pendidikan anak-anak petani; permasalahan kesehatan; atau dijadikan modal awal usaha yang biasanya membutuhkan dana besar. Untuk rumah tangga petani tua, membagi-bagikan warisan atau hibah juga menjadi penyebab utama mengapa rumah tangga mengakumulasi aset dan kemudian mendisakumulasi aset tersebut.

Aset berupa lahan sawah bisa saja sengaja disiapkan oleh petani untuk dijadikan warisan kepada anak-anak mereka ketika anak-anak tersebut memutuskan untuk berumah tangga sendiri. Keadaan tersebut kembali dijelaskan oleh Anggraeni (2009) bahwa beberapa rumah tangga terbukti menerima transfer kepemilikan lahan secara legal dari orang tua atau sanak famili mereka melalui sistem waris dan hibah. Selain itu, berdasarkan studi Ukoha et al. (2014), seiring petani bertambah tua, mereka cenderung merasa bahwa lebih menguntungkan untuk mengakusisi lahan dan meningkatkan luasan lahan pertanian.

Peningkatan akumulasi lahan sawah sebagai aset bagi rumah tangga usaha pertanian di Kabupaten Lamongan memiliki skala hasil yang menurun (decreasing return to scale). Hal ini terlihat dari koefisien umur kuadrat yang bernilai negatif. Seiring bertambahnya usia petani, petani cenderung meningkatkan aset lahan sawah, namun pertambahan marjinal aset tersebut selalu berkurang. Penyebab yang memungkinkan hal tersebut terjadi adalah bahwa seiring bertambahnya usia, kebutuhan petani akan semakin beragam dan meningkat sehinga kecenderungan untuk mengalokasikan 
pendapatan pada akumulasi aset juga akan menurun.

Ukuran rumah tangga yang digambarkan oleh jumlah anggota rumah tangga juga memiliki efek positif terhadap penguasaan lahan sawah. Hal ini sejalan dengan temuan Pomp (1995) dan penjelasan yang rasional dari hubungan positif tersebut adalah seiring bertambahnya jumlah anggota rumah tangga, jumlah tenaga kerja juga akan meningkat. Dalam kaitannya dengan lahan sebagai faktor kapital terhadap produksi komoditas pertanian, peningkatan jumlah tenaga kerja harus diimbangi dengan peningkatan kapital untuk menjaga produksi agar tetap efisien. Selain itu, meningkatnya jumlah anggota rumah tangga sebagai tenaga kerja membuat biaya produksi berkurang sehingga surplus bisa dialokasikan untuk meningkatkan lahan sawah. Selain itu, dalam kaitan lahan sawah berperan sebagai aset yang dipersiapkan petani untuk masa non produktif, peningkatan jumlah anggota rumah tangga akan memengaruhi keputusan petani dalam menentukan seberapa banyak aset atau tabungan yang harus dipersiapkan untuk biaya pendidikan, biaya kesehatan, atau warisan dan hibah.

Hubungan positif antara ukuran rumah tangga dan penguasaan lahan bisa dijelaskan melalui temuan Kimhi (2007). Kimhi (2007) berargumentasi bahwa peningkatan luasan lahan yang dikuasai memiliki hubungan positif dengan kelahiran anak. Namun, hal tersebut hanya relevan untuk anak laki-laki mengingat laki-laki lebih banyak terlibat pada aktivitas pertanian dibandingkan perempuan.

Jenis kelamin kepala rumah tangga memiliki hubungan yang negatif dengan penguasaan lahan. Hubungan negatif tersebut menunjukkan bahwa rata-rata luas lahan sawah yang dikuasai oleh rumah tangga usaha pertanian dengan kepala rumah tangga perempuan akan lebih sedikit jika dibandingkan dengan rata-rata luas lahan sawah yang dimiliki rumah tangga usaha pertanian dengan kepala rumah tangga laki-laki. Hasil tersebut sejalan dengan temuan Chendo et al. (2014). Penjelasan yang mungkin dari kondisi tersebut adalah karena aktivitas pertanian membutuhkan tenaga yang besar, maka laki-laki cenderung lebih banyak terlibat karena laki-laki lebih produktif daripada perempuan. Penjelasan mengenai kondisi bahwa perempuan cenderung memiliki lahan yang lebih sedikit dibandingkan laki-laki juga dijelaskan oleh Isaksson (2011). Laki-laki, secara budaya, menerima lahan dari keluarganya ketika laki-laki tersebut menikah dan hal tersebut tidak berlaku untuk perempuan. Sebaliknya, perempuan akan kehilangan hak atas lahan yang dimiliki suatu rumah tangga jika suami perempuan tersebut meninggal. Namun, penjelasan yang lebih menggambarkan mengapa di Kabupaten Lamongan perempuan cenderung memiliki lahan yang lebih sedikit perlu dibuktikan melalui riset yang lebih mendalam.

Variabel dummy kelompok rumah tangga berdasarkan luas kepemilikan lahan sawah dan lahan bukan sawah luas menunjukkan hasil yang signifikan. Dari hasil analisis regresi, terlihat bahwa rata-rata luas lahan sawah yang dimiliki rumah tangga dengan luas lahan sawah di atas rata-rata adalah 1.3 kali lebih tinggi dibandingkan rumah tangga dengan luas lahan sawah di atas rata. Selain itu, hasil analisis regresi juga menunjukkan bahwa rata-rata luas lahan sawah yang dimiliki rumah tangga dengan luas lahan bukan sawah di atas rata-rata 0.02 kali lebih rendah dibandingkan dengan rumah tangga yang memiliki lahan bukan sawah di bawah rata-rata.

\section{Koefisien Gini Penguasaan Lahan Pertanian di Kabupaten Lamongan}

Dari hasil analisis, koefisien Gini penguasaan lahan pertanian di Kabupaten Lamongan adalah 0.49. Berdasarkan klasifikasi nilai koefisien Gini oleh Bank Dunia, nilai koefisien Gini tersebut menunjukkan adanya ketimpangan penguasaan lahan pertanian yang moderat karena masih kurang dari 0.5. Meskipun begitu, ketimpangan penguasaan lahan di Kabupaten Lamongan harus tetap menjadi pertimbangan dalam menjalankan pembangunan pertanian karena adanya perubahan struktur agraria masih memungkinkan terjadinya konsentrasi lahan di kemudian hari. 
Tabel 2. Perbandingan Kepemilikan Lahan Pertanian pada Tiap Kategori Luasan Lahan Pertanian di Kabupaten Lamongan 2013

\begin{tabular}{ccc}
\hline Kategori Luas Lahan & \multicolumn{2}{c}{ Lahan Pertanian $\left(\mathrm{m}^{2}\right)$} \\
\cline { 2 - 3 } Pertanian $\left(\mathrm{m}^{2}\right)$ & \multicolumn{1}{c}{ Total } & Rata-Rata Luas Lahan \\
\hline$<1000$ & 5382571 & 324.3387 \\
$1000-1999$ & 40313320 & 1363.549 \\
$2000-4999$ & 231864341 & 3198.923 \\
$5000-9999$ & 312529670 & 6788.81 \\
$10000-19999$ & 206726928 & 12816.3 \\
$20000-29999$ & 64147134 & 23283.9 \\
$>30000$ & 88229933 & 50899.07 \\
\hline
\end{tabular}

Data pada tabel 2 menunjukkan bahwa rata-rata kepemilikan lahan pertanian kelompok rumah tangga terkecil (kurang dari $1000 \mathrm{~m}^{2}$ ) hanya sekitar $324.38 \mathrm{~m}^{2}$. Luasan tersebut memiliki selisih yang sangat jauh jika dibandingkan dengan ratarata kepemilikan lahan pertanian oleh kelompok pemilik lahan paling besar (lebih dari $30000 \mathrm{~m}^{2}$ ) yang mencapai angka $50899 \mathrm{~m}^{2}$. Jika dikaitkan dengan keragaman data, nilai koefisien Gini tersebut sudah sejalan. Besaran ketimpangan dari pemerataan sempurna digambarkan oleh kurva Lorenz pada Gambar 1.

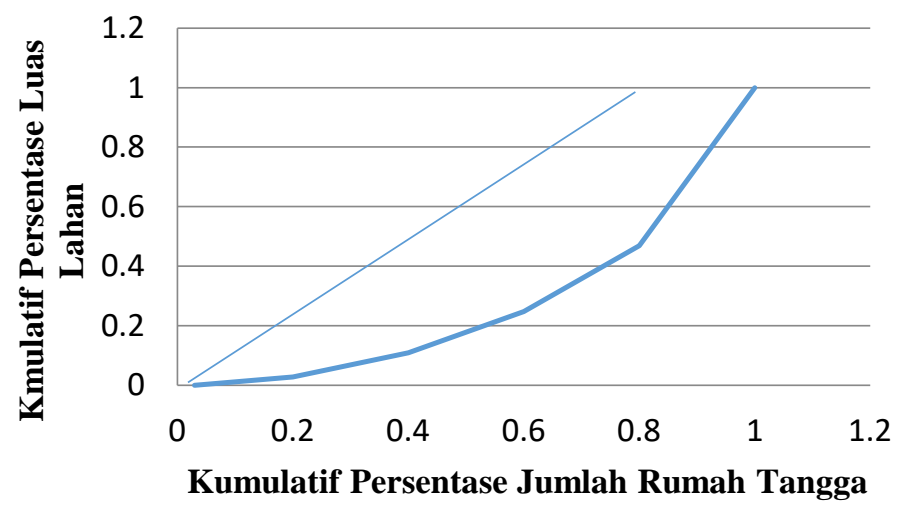

Gambar 1. Kurva Lorenz Penguasaan Lahan Pertanian di Kabupaten Lamongan

Kurva Lorenz penguasaan lahan pertanian di Kabupaten Lamongan menunjukkan bahwa sebanyak 3 persen rumah tangga usaha pertanian di Kabupaten Lamongan tidak menguasai lahan pertanian sama sekali. Selanjutnya, 20 persen rumah tangga usaha tani termiskin hanya menguasai 2.7 persen dari total lahan keseluruhan, 40 persen rumah tangga menguasai 11 persen, dari total keseluruhan lahan, 60 persen rumah tangga menguasai 24 persen total keseluruhan lahan, dan 80 persen rumah tangga menguasai 46 persen dari total lahan. Adanya ketimpangan penguasaan lahan di Kabupaten Lamongan ditunjukkan oleh fakta bahwa 20 persen rumah tangga usaha pertanian terkaya menguasai hingga 55 persen dari total lahan secara keseluruhan.
Beberapa kondisi yang bisa menerangkan penyebab tingginya ketimpangan penguasaan lahan pertanian antara lain dijelaskan oleh Darwis (2008). Darwis berargumentasi bahwa tingginya ketimpangan penguasaan lahan bisa disebabkan oleh sistem waris dan marjinalisasi petani kecil, polarisasi lahan oleh petani kaya, dan penguasaan lahan oleh penduduk luar wilayah. Kondisi-kondisi di atas diterangkan sebagai berikut:

1. Sistem waris di Indonesia mengikuti sistem pecah bagi. Lahan dibagi dan didistribusikan kepada mereka yang memiliki hak waris. Dengan sistem yang sedemikian rupa, luas lahan yang dikuasai dari satu generasi ke generasi berikutnya akan terus menyusut. Dengan kata lain, 
telah terjadi marjinalisasi lahan pada petani kecil. Selain adanya dari faktor waris, marjinalisasi lahan pada petani kecil disebabkan oleh kecenderungan petani kecil untuk menjual lahan karena mereka berhadapan dengan rendahnya pendapatan yang didapat dari lahan sempit. Ketika proses marjinalisasi tersebut terus terjadi, jumlah petani di pedesaan yang tidak memiliki lahan semakin meningkat dan ketimpangan penguasaan lahan semakin tinggi.

2. Secara umum, petani besar akan lebih efisien dalam mengelola asetnya, yaitu lahan pertanian. Pengelolaan aset yang efisien akan mendorong mereka memperoleh surplus dari aktivitas pertanian. Surplus usaha tersebut mereka gunakan untuk meningkatkan luasan lahan terutama melalui akusisi lahan dari petanipetani kecil. Karena hal itu, proses marjinalisasi terjadi di mana petani besar semakin kaya dan petani kecil semakin miskin. Proses tersebut pada akhirnya meningkatkan ketimpangan penguasaan lahan pertanian.

3. Kehadiran penduduk luar daerah dalam penguasaan lahan mendorong peningkatan ketimpangan. Penduduk luar daerah yang biasanya bermukim di kota memiliki kecenderungan untuk membeli lahan di desa dari petani-petani kecil. Konsekuensinya, polarisasi lahan terjadi dan jumlah petani yang tidak perlahan meningkat.

Suseno dan Suyatna (2007) menjelaskan bahwa ketimpangan penguasaan lahan merupakan hasil dari aktivitas pembangunan. Secara spesifik, ketimpangan penguasaan lahan terjadi akibat dicanangkannya kebijakan Revolusi Hijau. Sebagai konsekuensi dari Revolusi Hijau, proses transfer lahan dari petani kecil ke petani besar terjadi secara signifikan sehingga petani besar semakin besar demikian pula sebaliknya.

Bachriadi dan Wiradi (2011) mengatakan bahwa Revolusi Hijau tidak membawa dampak positif bagi ketimpangan penguasaan lahan dan justru meningkatkan ketimpangan tersebut. Proses industrialisasi yang terjadi selama Revolusi Hijau membuat petani kecil tersisih dari pembangunan. Suseno dan Suyatna (2007) juga mengatakan bahwa peran pemerintah terhadap pembentukan struktur lahan sangat besar. Oleh karena itu, secara tidak langsung pemerintah turut memperparah terjadinya ketimpangan penguasaan lahan. Menurut Suseno dan Suyatna, campur tangan pemerintah terjadi melalui proses modernisasi dan kapitalisasi pertanian.

Lemhanas (2012) menjelaskan faktor bahwa faktor demografi bisa mendorong terjadinya ketimpangan penguasaan lahan. Bachriadi dan Wiradi (2011) kembali menjelaskan faktor penyebab ketimpangan penguasan alahan. Menurut Bachriadi dan Wiradi, ketimpangan pengausaan lahan terjadi sebagai hasil dari politik dan kebijakan pertanian di era Orde Baru yang hanya memerhatikan pada penyediaan lahan dalam skala besar untuk inverstasi dan eksploitasi sumber daya alam. Pola penguasaan lahan di era Orde Baru juga menunjukaan bias penguasaan lahan. Konsentrasi dalam kepemilikan lahan dan penguasaannya sangat ditoleransi dan pemerintah tidak memberi perhatian kepada petani kecil atau petani tanpa lahan. Bachriadi dan Wiradi menjelaskan bahwa penyebab tingginya ketimpangan lahan berdasarkan data bahwa julmlah petani kecil telah menurun. Kondisi tersebut terjadi karena tingginya tingkat peralihan kepemilikan lahan dari petani kecil ke petani besar dan menyebabkan petani kecil dengan lahan kurang dari setengah hektar menjadi tidak berlahan kecuali untuk rumah dan pekarangan.

White dan Wiradi (1989) menjelaskan bahwa faktor utama penyebab ketimpangan penguasaan lahan yang tinggi adalah polarisasi dan proletarisasi di pedesaan sejak tahun 1963. Fakta tersebut diperoleh dari riset pada pola penguasaan lahan di 9 desa di Pulau Jawa. Petani kecil dan petani tidak berlahan hampir-hampir tidak memiliki kesempatan untuk memperoleh pendapatan dan memiliki investasi pada sektor pertanian. Sitorus et al. (2008) memberikan penjelasan bahwa polarisasi penguasaan lahan terjadi karena adanya proses transfer kepemilikan lahan dan karena rendahnya akses petani terhadap program pemerintah. Benu et al. (2013) menjelaskan bahwa peralihan kepemilikan lahan terjadi karena petani hanya mampu mendapatkan pendapatan yang sedikit dari tanah pertanian yang sempit sehingga mereka memilih untuk 
menjual lahan pertanian tersebut. Yunilisiah (1996) melakukan riset di wilayah transmigrasi dan menemukan bahwa faktor demografi, perbedaan kemampuan dalam implementasi teknologi pertanian, dan adanya sistem waris mendorong terjadinya ketimpangan penguasaan lahan.

Berbagai penjelasan dari riset-riset terdahulu mengenai penyebab ketimpangan penguasaan lahan bisa saja berlaku untuk studi kasus Kabupaten Lamongan. Namun, untuk mengetahui penyebab ketimpangan yang sebenarnya perlu dilakukan riset lebih dalam mengenai struktur kepemilikan lahan di Kabupaten Lamongan.

\section{SIMPULAN DAN SARAN Simpulan}

Dari analisis regresi, disimpulkan bahwa faktor yang memengaruhi penguasaan lahan sawah oleh rumah tangga usaha pertanian di Kabupaten Lamongan adalah usia kepala rumah tangga, jenis kelamin kepala rumah tangga, ukuran rumah tangga, jenis pendapatan utama, dan kemampuan rumah tangga dalam menguasai lahan yang diwakili oleh variabel dummy penguasaan lahan sawah, lahan bukan sawah, dan lahan sawah sekaligus bukan sawah. Usia kepala rumah tangga, ukuran rumah tangga, dummy untuk lahan sawah, dan dummy untuk lahan sawah sekaligus lahan bukan sawah memiliki efek positif di mana peningkatan usia kepala rumah tangga dan ukuran rumah tangga akan membuat rumah tangga cenderung menguasai lahan sawah yang lebih besar. Selain itu, rumah tangga yang memiliki lahan sawah dan lahan sawah sekaligus lahan bukan sawah di atas ratarata cenderung memiliki lahan sawah yang lebih besar. Koefisien jenis kelamin kepala rumah tangga memiliki tanda negatif, menandakan bahwa rata-rata kepemilikan lahan sawah oleh rumah tangga dengan kepala rumah tangga perempuan akan lebih sedikit dibandingkan dengan rumah tangga berkepala laki-laki. Selain itu, koefisien untuk dummy lahan bukan sawah negatif, menunjukkan bahwa jika rumah tangga menguasai lahan bukan sawah di atas rata-rata akan membuat rumah tangga tersebut cenderung memiliki lahan sawah yang lebih sedikit.

Untuk penguasaan lahan bukan sawah, ditemukan bahwa semua variabel signifikan memengaruhi penguasaan lahan kecuali usia kepala rumah tangga dan jenis kelamin. Usia yang tidak signifikan memengaruhi penguasaan lahan bukan sawah menunjukkan bahwa penguasaan lahan bukan sawah tidak terpengaruh usia kepala rumah tangga. Selanjutnya, rumah tangga dengan kepala rumah tangga perempuan tidak terbukti memiliki lahan yang lebih sedikit.

Koefisien Gini penguasaan lahan pertanian di Kabupaten Lamongan adalah 0.49 dan menunjukkan bahwa penguasaan lahan di Kabupaten Lamongan cenderung moderat.

\section{Saran}

Dari studi ini, beberapa saran yang diberikan antara lain:

1. Untuk penelitian selanjutnya yang terkait dengan penguasaan lahan, jumlah variabel penjelas perlu ditambah untuk memberikan acuan yang lebih jelas dalam menentukan faktor-faktor yang memengaruhi penguasaan lahan

2. Dari penelitian diperoleh fakta bahwa ratarata petani Indonesia berada pada usia tua. Oleh karena itu, pemerintah Kabupaten Lamongan dan pemerintah Indonesia pada umumnya perlu meningkatkan minat generasi muda untuk terlibat dalam sektor pertanian melalui pemberian insentif, pendidikan, dan sosialiasi pentingnya sektor pertanian bagi keberlangsungan ketahanan pangan

Mempertimbangkan bahwa lahan pertanian menjadi aset bagi sebagian besar rumah tangga petani, kebijakan yang membatasi adanya alih kepemilikan lahan perlu dibuat. Hal ini terkait dengan dampak langsung alih kepemilikan tersebut terhadap ketimpangan penguasaan lahan pertanian yang pada akhirnya memengaruhi keberhasilan program ketahanan pangan yang sudah digagas sebelumnya. 


\section{DAFTAR PUSTAKA}

Aghion P, Caroli E, Garcia-Penalosa C. 1999. Inequality and Economic Growth: The Perspective of The New Growth Theories. Journal of Economic Literature. 37 (4): 1615-1660. DOI: 10. 1257/jel.37.4.1615.

Alesina A, Rodrik D.1994. Distributive Politics and Economic Growth. Qarterly Journal of Economics. 109 (2): 465-490.

Anggraeni, L. 2009. Credit Access and the Increase of Farmer's Asset in Mountainous Areas: The Case of Kemang Village in West Java [disertasi]. Tokyo (JP): The University of Tokyo

Bachriadi D, Winardi G. 2011. Enam Dekade Ketimpangan: Masalah Penguasaan Tanah di Indonesia. Bandung (ID): Agrarian Resource Center (ARC), Bina Desa, Konsorsium Pembaruan Agraria (KPA)

Bazhenova OV, Krytsun KI. 2013. The Modigliani-Addo-Brumberg Life-cycle Model: Applying to Ukraine's Economy. EKONOMIKA. 92(4).

Ben-Chendo GN, Korie OC, Essien UA, Uhuegbulem IJ. 2014. Determinants of Land Holding Size among Rice Farmers in Southeast Nigeria. Asian Review of Environmental and Earth Sciences: Asian Online Journal. 1(3): 55-60.

Benu NM, Maryunani, Sugianto, Kindangen P. 2013. Analysis of Land Conversion and Its Impacts and Strategies in Managing Them in City of Tomohon, Indonesia. Asian Transactions on Basic and Applied Sciences. 3(-): 65-726

Bodie Z, Treussard J, Willen P. 2007. The Theory of Life-cycle Saving and Investing. Federal Reserve Bank of Boston. Public Policy Discussion Paper 07-3.

Booth A. 2002. The Changing Role of Non-Farm Activities in the Soeharto Era: An Assesment. Bulletin of Indonesia Economic Studies. 36(1): 73-104

Borella M, Rossi M. 2014. Asset Accumulation and Decumulation Over The Lifecycle: The Role of Financial Literacy. Network for Studies on Pensions, Aging, and Retirement (NETSPAR). 39.
[BPS] Badan Pusat Statistik. 2013. Potensi Pertanian Indonesia: Analisis Hasil Pencacahan Lengkap Sensus Pertanian 2013. Katalog BPS. Jakarta (ID): Badan Pusat Statistik.

Chaudhry IS, Malik S, Hassan A. 2009. The Impact of Socioeconomic and Demographic Variables on Poverty: A Village Study. The Lahore Journal of Economics. 14(1): 39-68.

Darwis, V. 2008. Keragaan Penguasaan Lahan Sebagai Faktor Utama Penentu Pendapatan Petani. Seminar Nasional Dinamika Pembangunan Pertanian dan Pedesaan: Tantangan dan Peluang Bagi Peningkatan Kesejahteraan Petani. 19 November 2008; Bogor, Indonesia. Bogor (ID): Pusat Analisis Sosial Ekonomi dan Kebijakan Pertanian Departemen Pertanian.

Deininger K, Squire L. 1996. A New Data Set Measuring Income Inequality. The World Bank Economic Review 10(3): 565-591

Deininger K, Feder G, Gordillo de Anda G, Munro-Faure P. 2003. Land Policy to Facilitate Growth and Poverty Reduction. Inside: Cox M, Munro-Faure P, Dey-Abbas J, Rouse J, Bass S, editor. Land Reform: Land Settlement and Cooperatives/Special Edition. Rome (IT): Food and Agricultural Association (FAO). Page 5-18

Deininger K, Jin S, Nagarajan KH. 2003. Land Reforms, Poverty Reduction, and Economic Growth: Evidence from India. The World Bank Development Research Group. Policy Research Working Paper 4448.

[EPAT] The Environmental and Natural Resources Policy and Training Project. 1995. The Structure of Land Holding, Land Management, and Degradation

Gujarati DN. 2004. Basic Econometrics $4^{\text {th }}$ Edition. New York City (USA): McGraw Hill Hidalgo FD, Naidu S, Nichter S, Richardson N. 2008. Occupational Choices: Economic Determinants of Land Invasions. University of California.

Isaksson AS. 2011. Unequal Property Rights: A Study of Land Right Inequalities in Rwanda. University of Gothenburg. Working Paper in Economics No 507 
Jamal H, Khan AJ. 2005. Impact of Ownership and Concentration of Land on Schooling. The Lahore Journal of Economics. 10(2): 1-14

Juanda B. 2009. Ekonometrika: Pemodelan dan Pendugaan. Bogor (ID): IPB Press.

Kano H. 1990. Pagelaran: Anatomi Sosial Mubyarto. 1973. Pengantar Ekonomi Pertanian. Ekonomi Pelapisan Masyarakat Tani di Sebuah Desa di Jawa Timur. Yogyakarta (ID): Gadjah Mada University Press.

Kasryno, F. 2000. Menempatkan Pertanian sebagai Basis Ekonomi Indonesia: Memantapkan Ketahanan Pangan dan Mengurangi Kemiskinan. Prosiding Widyakarya Pangan dan Gizi. Jakarta (ID): LIPI.

Khattak NR, Hussain A. 2008. An Assesment of The Inequality in Income and Land Holdings among Rural Rice Farmers of District Swat. Munich Personal RePEc Archive (MPRA). MPRA Paper No. 42033.

Kimhi A. 2007. Does Land Reform in Transition Countries Increase Child Labor? Evidence from The Republic of Georgia. The Hebrew University of Jerusalem. Discussion Paper No. 4.07

[Lemhanas] Lembaga Ketahanan Nasional. 2012. Revitalisasi Kebijakan Agraria Guna Meningkatkan Kesejahteraan Rakyat dalam Rangka Ketahanan Nasional. Jurnal Kajian Lemhanas RI Edisi 14

Matteo DL. 1997. The Determinants of Wealth and Asset Holding in Nineteenth-Century Canada: Evidence from Microdata. The Journal of Economic History. 57(4): 907. 934.

Maxwell D, Wiebe K. 1998. Land Tenure and Food Security: A Review of Concepts, Evidence, and Methods. Land Tenure Center University of Wisconsin-Madison.Research Paper No. 129.

Mendola M, Simtowe F. 2014. The Welfare Impact of Land Distribution: Evidence from a Quasi-Experimental Initiative in Malawi. Centro Studi Luca D'Agliano. Development Studies Working Paper.

Milligan, K. 2004. Life-Cycle Asset Accumulation and Allocation in Canada. National Bureau of Economic Research (NBER). Working Paper 10860.

Minardi S. 2009. Optimalisasi Pengelolaan Lahan Kering untuk Pengembangan Pertanian
Tanaman Pangan. Surakarta (ID): UPT Perpustakaan UNS. Modigliani, F. 1986. The Life Cycle Hypothesis of Saving, the Demand for Wealth and the Supply of Capital. Social Research. 33(2).

Jakarta (ID): Lembaga Penelitian, Pendidikan, dan Penerapan Ekonomi dan Sosial (LP3ES).

Nuryartono N. 2005. Impact of Smallholder's Access to Land amd Credit Markets on Technology Adoption and Land Use Decisions: The Case of Tropical Forest Margins in Central Sulawesi-Indonesia [disertasi]. Goettingen (DE): Georg August University of Goettingen

Pomp, M. 1995. Determinants of Smallholder Landownership: Evidence from South Sulawesi, Indonesia. The Journal of Development Studies. 31(6): 845-867.

Rahman MH, Manprasert S. 2006. Landlessness and Its Impact on Economic Development: A Case Study on Bangladesh. Journal of Social Sciences. 2(2): 54-60.

Siahaan H. 1977. Pemilikan dan Penguasaan Tanah Adopsi Teknologi Pertanian Modern dan Disparitas Pendapatan di Daerah Pedesaan. Yogyakarta (ID): Lembaga Studi Kawasan dan Pedesaan Universitas Gadjah Mada

Sitorus F, Dharmawan AH, Fadjar U, Sihaloho M. 2008. Perubahan Struktur Agraria dan Diferensiasi Kesejahteraan Petani.

Supriyati. 2011. Dinamika Ekonomi Ketenagakerjaan Pertanian: Permasalahan dan Kebijakan Strategis Pengembangan. Pusat Analis Sosial Ekonomi dan Kebijakan Pertanian Departemen Pertanian.

Supriyati, Saptana, Supriyatna Y. 2011. Hubungan Penguasaan Lahan dan Pendapatan Rumah Tangga di Pedesaan. Pusat Penelitian dan Pengembangan Sosial Ekonomi Pertanian Departemen Pertanian.

Suseno D, Suyatna H. 2007. Mewujudkan Kebijakan Pertanian yang Pro-Petani. Jurnal Ilmu Sosial dan Ilmu Politik.10(3): 267-294. 
Susilowati HS, Hutabarat B, Rachmat M, Sugiarto, Supriyati, Zakaria AK, Supriyadi H, Purwoto A, Supadi, Winarso B et al. 2010. Indikator Pembangunan Pertanian dan Pedesaan: Karakteristik Sosial Ekonomi Petani Padi. Pusat Analisis Sosial Ekonomi dan Kebijakan Pertanian Departemen Pertanian.

Tang J, Wang X. 2009. Analysis of The Land Use Structure Changes based on Lorenz Curve. Environmental Monitoring and Assesment. 151(1-4):175-180. Tersedia di: http://www.link.springer.com.

Timmer CP. 1975. The Political Economy of Rice in Asia: Indonesia. Food Research Institute Studies. 14(3): 197-231.

Todaro MP, Smith SC. 2006. Economic Development: The Addison-Wesley series in Economics. New-Jersey (USA): Pearson AddisonWesley.

Todaro MP, Smith SC. 2011. Economic Development $11^{\text {th }}$ Edition. Singapore (SG): Prentice-Hall.

Ukoha HA, Korie OC, Ibekwe UC, ChidiebereMark NM, RD Ejike, Okparadim GI. 2014. Determinants of Access to Landholding in Female-Headed Cassava Farm households in Abia State, Southeast Nigeria. Journal of Biology, Agriculture and Healthcare. 4(4)

Vollrath, D. 2006. Geography and the Determinants of Land Distribution: Evidence from the United States. SSRN Electronic Journal. DOI: 10.2139/ssrn.938010.

Vollrath D. 2007. Land Distribution and International Agricultural Productivity.
American Journal of Agricultural Economic. 89(1): 2012-216

White B, Wiradi G. 1989. Agrarian and Nonagrarian Bases of Inequality in Nine Javanese Villages. In: Hart G, Turton A, White B, editors. Agrarian Trasnformation: Local Processes and the States in Southeast Asia. Berkeley (USA): University of California Press. Page 266-302.

Weber J, Key N. 2014. Leveraging Wealth from Farmland Apperciation: Borrowing, Land Ownership, and Farm Expansion. Munich Personal RePEc Archive (MPRA) [Internet]. [diunduh 2015 Jul 07]; MPRA Paper No. 58899. Tersedia di: http://www.mpra.ub.unimuenchen.de/58899/.

Wiradi G, Makali. 1984. Penguasaan Tanah dan Kelembagaan. In: Kasryno F, editor. Prospek Pembangunan Ekonomi Pedesaan Indonesia. Jakarta (ID): Yayasan Obor Indonesia.

Yunilisiah. 1996. Pola Penguasaan Tanah dan Kualitas Hidup Rumah Tangga Petani di Desa Transmigrasi [Tesis]. Bogor (ID): IPB.

Zander D, Durr J. Dynamics in Land Tenure, Local Power and The Peasant Economy: The Case of Peten, Guatemala. International Conference on Global Land Grabbing 6-8 April 2011. Land Deal Politics Initiative

Zheng X, Xia T, Yang X, Yuan T, Hu Y. 2013. The Land Gini Coefficient and Its Application for Land Use Structure Analysis in China. PLOS ONE. 8(10). 